\title{
Bacteriocin production by spray-dried lactic acid bacteria
}

\author{
J. Silva, A.S. Carvalho, P. Teixeira and P.A. Gibbs \\ Escola Superior de Biotecnologia, Universidade Católica Portuguesa, Rua Dr António Bernardino de Almeida, \\ Porto4200-072, Portugal
}

2001/196: received 2 July 2001, revised 4 October 2001 and accepted 15 October 2001

J. SILVA, A.S. CARVALHO, P. TEIXEIRA AND P.A. GIBBS. 2002.

Aims: Cell survival and antagonistic activity against Listeria innocua, Listeria monocytogenes and Staphylococcus aureus were investigated after spray-drying three bacteriocin-producing strains of lactic acid bacteria: Carnobacterium divergens, Lactobacillus salivarius and Lactobacillus sakei.

Methods and Results: Bacterial cell concentrates were spray-dried and stored at $4^{\circ} \mathrm{C}$ and $18^{\circ} \mathrm{C}$ and $0.3 \% \mathrm{ERH}$ (equilibrium relative humidity). Enumeration and antagonistic activity were evaluated before and after spray-drying and at regular intervals during storage.

Conclusions: A higher survival rate was obtained when survival was performed at $4^{\circ} \mathrm{C}$. With the exception of Carnobacterium divergens which lost the inhibitory activity against Staph. aureus after drying, antagonistic production was not affected by the process nor by the storage. Of the three species studied, Lact. salivarius showed the highest resistance to the spray-drying and storage processes.

Significance and Impact of Study: Spray-drying is a potentially useful process for large scale production of dried powders containing viable organisms with antagonistic activity against pathogens.

\section{INTRODUCTION}

Despite the recent progress in food biotechnology, with the introduction of modern technologies and safety concepts (e.g. HACCP), the problem of food safety and security remains to be solved. Protective cultures and associated antagonistic substances ('biopreservation') should be considered an additional factor with the potential for improving the microbiological safety of food. Their implementation should support good manufacturing practices, thereby reducing risks of growth and survival of pathogens and spoilage micro-organisms (Kim and Bhowmik 1990; Mauriello et al. 1999).

Lactic acid bacteria (LAB) have traditionally been used in food processing because of their ability to improve the organoleptic characteristics and healthiness of foodstuffs. Different antimicrobials, such as lactic acid and acetic acid, hydrogen peroxide, carbon dioxide and bacteriocins, produced by these bacteria, can inhibit pathogenic and spoilage micro-organisms, extending the shelf-life and enhancing the safety of food products (Aymerich et al. 2000).

Correspondence to: 7. Silva, Escola Superior de Biotecnologia, Universidade Catolica Portuguesa Rua Dr António Bernardino de Almeida, Porto 4200-072, Portugal (e-mail: joana@morango.esb.ucp.pt).
Increasing consumer demand for natural food additives has focused interest on bacteriocins. Bacteriocins of LAB are considered natural biopreservatives, as it is assumed that bacteriocins are degraded by the proteases of the gastrointestinal tract (Cintas 1995), and most of the LAB are considered as GRAS (Generally Recognized as Safe) microorganisms (Holzapfel et al. 1995).

The application of bacteriocins as food preservatives could be achieved either by using the bacteriocinogenic strain as a starter culture and/or a protective culture, or by using the bacteriocin as a food additive. Therefore, from a commercial point of view, an inexpensive method for large-scale production of cultures containing high levels of viable bacteriocin producers, in a form suitable for product applications, is highly desirable (Gardiner et al. 2000). In previous studies researchers have investigated the production of spray-dried powders of Lactobacillus spp. (Kim and Bhowmik 1990; Teixeira et al. 1995). In addition to maintaining the viability of cultures, it is important that their bacteriocinogenic properties are maintained following the spray-drying process.

Spray-drying can be used to produce large amounts of dairy ingredients relatively inexpensively, the spray-dried powders can be transported at a low cost and can be stored in a stable form for prolonged periods (Gardiner et al. 2000). 
Because of the advantages of spray-drying, in the present study we investigated the use of this method as a way to preserve bacteriocinogenic strains, e.g. Lact. sakei, Lact. salivarius and Carn. divergens. The purpose of this study was to evaluate the antimicrobial activity of these LAB strains, which are active against L. monocytogenes, L. innocua and Staph. aureus (Hugas et al. 1995; Pilet et al. 1995; Duffes et al. 1999; Dunne et al. 1999; Pascual et al. 1999), before and after spray-drying.

\section{MATERIALS AND METHODS}

\section{Bacterial cultures and media}

Lact. sakei CTC 494 and Lact. salivarius CTC 2197 were generously supplied by Dr Marta Hugas from Spain. Carn. divergens isolated from trout intestine by Pilet et al. 1995) was generously supplied by ENITIAA (France).

Lact. sakei and Lact. salivarius were grown in MRS broth (LAB M, Bury, UK) (DeMan et al. 1960) at $30^{\circ} \mathrm{C}$ and $37^{\circ} \mathrm{C}$, respectively. Carn. divergens was grown in Elliker medium (Elliker et al. 1956) at $30^{\circ} \mathrm{C}$ for $24 \mathrm{~h}$. Working cultures were stored as stab agar medium at $4^{\circ} \mathrm{C}$. Fresh stab cultures were prepared from working cultures every month. L. monocytogenes T100 and L. innocua 2030 c (tetracycline resistant), previously isolated from cold smoked fish by Escola Superior de Biotecnologia, were grown in tryptic soy broth (TSB, LAB M) supplemented with $0.6 \%$ yeast extract (LAB M) at $37^{\circ} \mathrm{C}$. Staph. aureus NCTC 08532 (supplied by Serviços de Microbiologia, ESB, Porto, Portugal) was grown in TSB at $37^{\circ} \mathrm{C}$ for $24 \mathrm{~h}$.

\section{Preparation of feed solution for spray-drying}

Overnight cultures of each strain of lactic acid bacteria were inoculated at $1 \% \mathrm{v} / \mathrm{v}$ into MRS broth and Elliker broth and incubated at $30^{\circ} \mathrm{C}$ or $37^{\circ} \mathrm{C}$ for $24 \mathrm{~h}$. After centrifugation at $7000 \mathrm{~g}$ for $15 \mathrm{~min}$ at $4^{\circ} \mathrm{C}$, the cells were resuspended in an equal volume of sterile $11 \% \mathrm{wv}^{-1}$ skim-milk powder (Oxoid). Each sample was then directly spray-dried.

\section{Spray-drying and storage}

Samples were spray-dried in a laboratory scale apparatus (Niro Atomizer, Gladsaxevej, Denmark). Moisture in spray droplets produced by the atomization of the feed liquid by a vaned wheel (rotary atomizer) rotating at high speed, was evaporated in a vertical co-current drying chamber, $0.8 \mathrm{~m}$ diameter and $0.6 \mathrm{~m}$ height. Spray-drier conditions were: outlet air temperature $70^{\circ} \mathrm{C}$, inlet air temperature $200^{\circ} \mathrm{C}$ and atomizing air pressure 5 Bar. Powder was collected in a single cyclone separator. Samples of the spray-dried inoculum were stored at $4^{\circ} \mathrm{C}$ and $18^{\circ} \mathrm{C}$ in hermetically sealed glass bottles in which the ERH (equilibrium relative humidity) was controlled by equilibrium with silica.

\section{Enumeration}

Before drying, the organisms were enumerated on Elliker agar in the case of Carn. divergens and on MRS agar for the other two cultures in the study, by the drop count technique (Miles and Misra 1938). Each sample of spray-dried bacteria was rehydrated to the original volume with deionized water. The cells were allowed to rehydrate for 2 min under vigorous shaking and the suitable dilutions were plated as described above. Plates were incubated at $30^{\circ} \mathrm{C}$ (Carn. divergens and Lact. sakei) and $37^{\circ} \mathrm{C}$ (Lact. salivarius) for $24 \mathrm{~h}$ before enumeration.

\section{Bacteriocin spectrum of activity}

The inhibitory activity of the three bacteriocin producers against the L. innocua, L. monocytogenes and Staph. aureus strains was tested at various intervals during storage by the deferred antagonism test (Barefoot and Klaenhammer 1984). From each lactic acid bacteria, $10 \mu \mathrm{l}$ were placed on the surface of a solid medium TSYE overlay seeded with $100 \mu \mathrm{l}$ of an overnight target culture. The plates were examined after overnight incubation at $37^{\circ} \mathrm{C}$.

\section{Statistical analysis}

Statistical analysis was done with the ANOVA methodology using Statview ${ }^{\text {TM }}$ Package (Abacus Concepts, Berkeley, CA, USA) using as independent variable the storage time.

The experiments were repeated at least three times. Viable counts on MRS agar were converted to $\log \mathrm{cfu} \mathrm{ml}^{-1}$. Differences were considered significant at $P<0.05$. The error bars on the figures indicate the mean standard deviations for the data points.

\section{RESULTS}

In the present study, the use of spray-drying as a way to prepare dairy-based powders containing viable cultures of Lact. sakei, Lact. salivarius and Carn. divergens with antagonistic activity against selected pathogens was investigated. For each strain, three independent experiments were performed.

\section{Survival kinetics of spray-dried cell concentrates during storage}

The experimental results for the survival of Lact. salivarius, Lact. sakei and Carn. divergens during drying and subsequent storage at different temperatures $\left(4^{\circ} \mathrm{C}\right.$ and $\left.18^{\circ} \mathrm{C}\right)$ are shown in Table 1 and Fig. 1, respectively. For all strains, no 
significant differences were observed in the number of viable cells before and after drying. Survival of Carn. divergens and Lact. sakei decreased during the storage time at $4^{\circ} \mathrm{C}$ and $18^{\circ} \mathrm{C}$ being the rate of decrease higher at the higher temperature of storage $(P<0 \cdot 05)$. The survivor curve of Lact. sakei showed the greatest decrease during storage at both temperatures, and no survivors were observed at the end of the 2 nd month of storage at $18^{\circ} \mathrm{C}$.

Until the 3rd month of storage there was no significant survival decrease of Lact. salivarius at $4^{\circ} \mathrm{C}$ and $18^{\circ} \mathrm{C}$.

\section{Effect of spray-drying on bacteriocin production}

The effect of spray-drying and storage in the dried state on the bacteriocinogenic activity of lactobacilli was investigated. The results obtained by deferred antagonism assay to detect the ability of bacteriocin-producing strains to inhibit L. innocua, L. monocytogenes and Staph. aureus are reported in Table 2.

In the case of Carn. divergens there was a loss of antagonistic activity against Staph. aureus immediately after spray-drying but not against the two Listeria spp. During spray-drying and during storage, Lact. salivarius maintained the bacteriocin activity against $L$. innocua, L. monocytogenes and Staph. aureus at least during the 3 months of storage. Lact. sakei maintained its bacteriocin activity while viable.

\section{DISCUSSION}

In this study it was found that the strains investigated, varied considerably in their ability to survive storage in dried state.

Results showed that the storage temperature was a critical parameter affecting the survival of the micro-organisms. In all experiments, survival rates were higher at the lower temperature of storage.

The bacteriocin produced by Lact. sakei CTC 494 (sakacin K), by Lact. salivarius CTC 2197 and by Carn. divergens (divercin $\mathrm{V} 41$ ) was reported as having an antagonistic activity against both Listeria strains and Staph. aureus (Lact. sakei and Lact. salivarius) and against Listeria spp. (Carnobacterium) (Duffes et al. 1995; Hugas et al. 1995; Pascual et al. 1999; and Pilet et al. 1995). In this study, it was demonstrated that the spray-drying process did not affect this antagonistic activity of Lact. sakei and Lact. salivarius. Similar results were obtained by Gardiner et al. (2000) and Mauriello et al. (1999). Carn. divergens, however, lost its antagonistic activity against Staph. aureus,
Table 1 Survival of Lact. sakei, Lact. salivarius and Carn. divergens before and after spray-drying

Fig. 1 Survival of spray dried Lact. sakei, Lact. salivarius and Carn. divergens during storage at $18^{\circ} \mathrm{C}$ and $4^{\circ} \mathrm{C}$ under controlled ERH $(P<0 \cdot 05) .(\square),\left(\right.$ Carn. divergens $18^{\circ} \mathrm{C}$; $(\boldsymbol{\square})$, Carn. divergens $4^{\circ} \mathrm{C} ;(\triangle)$, Lact. sakei $18^{\circ} \mathrm{C} ;(\boldsymbol{\Delta})$, Lact. sakei $4^{\circ} \mathrm{C} ;(\diamond)$, Lact. salivarius $18^{\circ} \mathrm{C}$; $(\diamond)$, Lact. salivarius $\left.4^{\circ} \mathrm{C}\right)$

\begin{tabular}{|c|c|c|c|c|c|c|}
\hline & \multicolumn{2}{|c|}{ Lact. sakei } & \multicolumn{2}{|c|}{ Lact. salivarius } & \multicolumn{2}{|c|}{ Carn. divergens } \\
\hline & $4^{\circ} \mathrm{C}$ & $18^{\circ} \mathrm{C}$ & $4^{\circ} \mathrm{C}$ & $18^{\circ} \mathrm{C}$ & $4^{\circ} \mathrm{C}$ & $18^{\circ} \mathrm{C}$ \\
\hline Before spray-drying & $8 \cdot 73$ & $8 \cdot 75$ & $8 \cdot 84$ & $8 \cdot 82$ & $8 \cdot 53$ & $8 \cdot 45$ \\
\hline After spray-drying & $8 \cdot 4$ & $8 \cdot 3$ & $8 \cdot 83$ & $8 \cdot 84$ & $8 \cdot 17$ & $8 \cdot 2$ \\
\hline
\end{tabular}

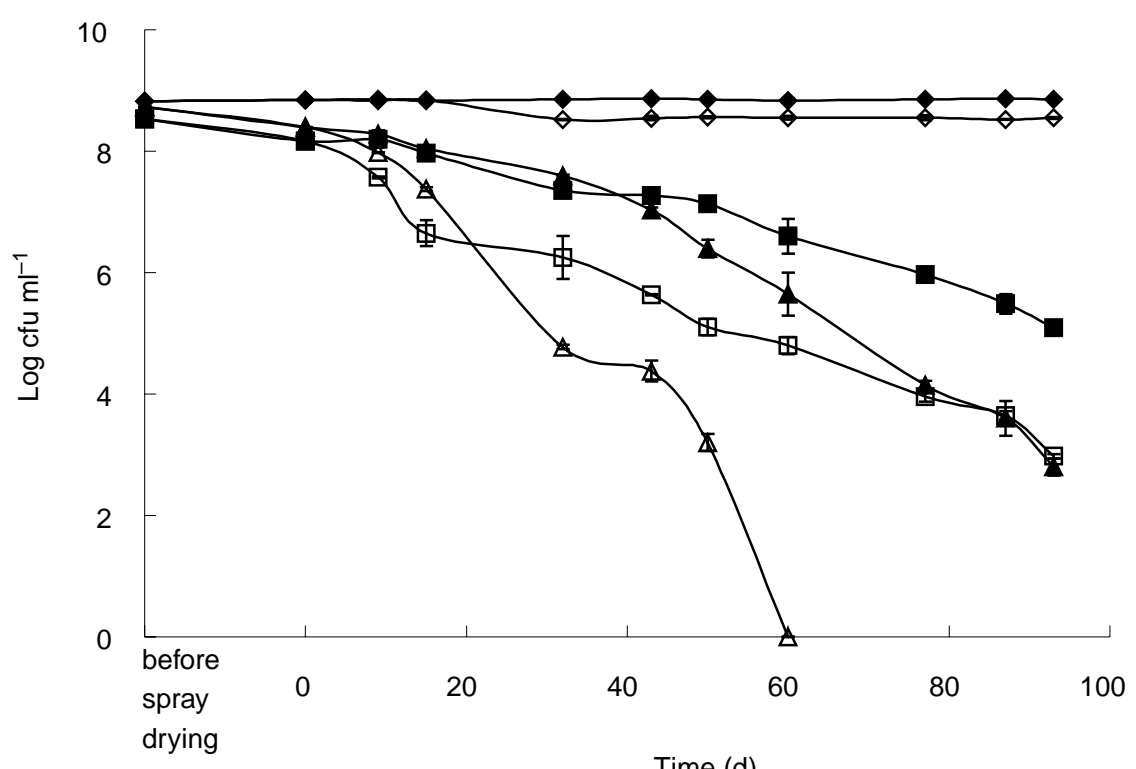


Table 2 Sensitivity of three pathogenic micro-organisms to bacteriocins produced by Lact. salivarius, Lact. sakei and Carn. divergens, before and after drying and during storage, at $18^{\circ} \mathrm{C}$, as determined by deferred antagonism assay

\begin{tabular}{|c|c|c|c|c|c|c|c|c|c|c|c|c|c|c|c|c|c|c|c|c|c|}
\hline \multirow[b]{2}{*}{ Time (d) } & \multicolumn{7}{|c|}{ Carn. divergens } & \multicolumn{7}{|c|}{ Lact. sakei } & \multicolumn{7}{|c|}{ Lact. salivarius } \\
\hline & BSD & 0 & 9 & 32 & 50 & 77 & 93 & BSD & 0 & 9 & 32 & 50 & 77 & 93 & BSD & 0 & 9 & 32 & 50 & 77 & 93 \\
\hline L. monocytogenes & + & + & + & + & + & + & + & + & + & + & + & + & $*$ & $*$ & + & + & + & + & + & + & + \\
\hline Staph. aureus & + & - & - & - & - & - & - & + & + & + & + & + & $*$ & * & + & + & + & + & + & + & + \\
\hline
\end{tabular}

+ , clearly defined zone of inhibition surrounding the producing bacterial colony

- , no inhibition

$\mathrm{BSD}=$ before spray drying

*no survivors

but not against $L$. innocua and L. monocytogenes. The production of more than one bacteriocin by a single organism has already been reported (Bhugaloo-vial et al. 1996) and Bhugaloo-vial reported the isolation and classification of two class II a bacteriocins produced by Carn. piscicola V1 which exhibit significant differences in their inhibitory activities against target Gram-positive bacteria. To our knowledge, this is the first time that loss of antagonistic activity during spray-drying is reported. This phenomenon might be explained by a possible loss of the plasmid responsible for that inhibitory activity. Bacteriocin production mediated by plasmids has already been reported (Kim and Bhowmik 1990; Hugas et al. 1995; Pilet et al. 1995).

In conclusion, spray-drying is potentially a useful process for large scale production of dried powders containing viable organisms with antagonistic activity against pathogens. However, this can not be generalized and for each individual organism, it must be investigated if these characteristics are maintained. Furthermore, given the numerous applications of skim milk powders, not only in dairy products but also in food such as instant desserts and mayonnaise, it is possible that the resulting culture containing powders could be used in a wide range of functional food applications, i.e. having antimicrobial properties in those foods.

\section{ACKNOWLEDGEMENTS}

Financial support for authors Silva and Carvalho was provided, respectively, by a $\mathrm{PhD}$ fellowship issued by PRAXIS XXI (JNICT-BD-19713-99 and JNICT-BD18512-98, respectively).

\section{REFERENCES}

Aymerich, T., Artigas, M.G., Monfort, J.M. and Hugas, M. (2000) Effect of sausage ingredients and additives on the production of enterocins A and B by Enterococcus faecium CTC492. Optimization of in vitro production and anti-listerial effect in dry fermented sausages. Fournal of Applied Microbiology 88, 686-694.

Barefoot, S.F. and Klaenhammer, T.R. (1984) Purification and characterization of the Lactobacillus acidophilus bacteriocin lactacin B. Antimicrobiological Agents Chemotherapy 26, 328-334.

Bhugaloo-vial, P., Dousset, X., Metiver, A., Sorokine, O., Anglade, P., Boyaval, P. and Marion, D. (1996) Purification and amino acid sequences of Piscicocins Vla and V1b, two class Iia bacteriocins secreted by Carnobacterium piscicola V1 that display significantly different levels of specific inhibitory activity. Applied and Environmental Microbiology 62, 4410-4416.

Cintas, L. (1995) Caracterización Bioquimica Y Genética Parcial de la Pediocina L50, Una Nueva Bacteriocia Producida Por Pediococcus Acidilactici. L50 aislado de embutidos crudos curados. Doctoral Thesis. Madrid Autonomous University.

DeMan, J., Rogosa, C.M. and Sharpe, E. (1960) A medium for the cultivation of Lactobacilli. Fournal of Applied Bacteriology 23, $130-135$.

Duffes, F., Leroi, F., Boyaval, P. and Dousset, X. (1999) Inhibition of Listeria strains in a simulated cold smoked fish system stored at $4^{\circ} \mathrm{C}$. International Fournal of Food Microbiology 47, 33-42.

Dunne, C., Murphy, L., Flynn, S., O’Mahony, L., O'Halloran, S., Feeney, M., Morrissey, D., Thornton, G., Fitzerald, G., Daly, C., Kiely, B., Quigley, E.M.M., O'Sullivan, G.C., Shanahan, F. and Collins, J.K. (1999) Probiotics: from myth to reality. Demonstration of functionality in animal models of disease and in human clinical trials. Antonie Leeumenhoeck 76, 279-292.

Elliker, P.R., Anderson, A.W. and Hannesson, G. (1956) An agar culture medium for lactic acid streptococci and lactobacilli. Fournal of Dairy Science 39, 1611.

Gardiner, G.E., O’Sullivan, E., Kelly, Y., Auty, M.A.E., Fitzgerald, G.F., Collins, Y.K., Ross, R.P. and Stanton, C. (2001) Comparative survival rate of human-derived probiotic Lactobacillus paracasei and L. salivarius strains during heat treatment and spray-drying. Applied and Environmental Microbiology 66, 2605-2612.

Holzapfel, W.H., Geisen, R. and Schillinger, U. (1995) Biological preservation of foods reference to protective cultures, bacteriocins and food-grade enzymes. International Fournal of Food Microbiology 24, 343-362.

Hugas, M., Garriga, M., Aymerich, M.T. and Monfort, J.M. (1995) Inhibition of Listeria in dry fermented sausages by the bacteriocinogenic Lact. Sake CTC 494. Fournal of Applied Bacteriology 79, 322-330. 
Kim, S.S. and Bhowmik, S.R. (1990) Survival of lactic acid bacteria during spray-drying of plain yoghurt. Fournal of Food Science 55, 1008-1010.

Mauriello, G., Aponte, M., Andolfi, R. and Moschetti and Villani, F. (1999) Spray-drying of bacteriocin-producing lactic acid bacteria. Fournal of Food Protection 62 7, 773-777.

Miles, A.A. and Misra, S.S. (1938) The estimation of the bactericidal power of blood. Fournal of Hygiene (Cambridge) 38, 732-749.

Pascual, M., Hugas, M., Badiola, J.I., Monfort, J.M. and Garriga, M. (1999) Lactob. saliv. CTC 2197 prevents Salmonella enteritidis colonization in chickens. Applied and Environmental Microbiology 65, 4981-4986.

Pilet, M., Dousset, X., Barré, R., Novel, G. and Desmazeaud and Piard, J. (1995) Evidence for two bacteriocins produced by Carnobacterium piscicola and Carnobacterium divergens isolated from fish and active against Listeria monocytogenes. Fournal of Food Protection 58, 256-262.

Teixeira, P., Castro, H. and Kirby, R. (1995) Spray-drying as a method for preparing concentrated cultures of Lactobacillus bulgaricus. Journal of Applied Microbiology 78, 456-462. 